\title{
Art and Piety in Lutheran Germany and Beyond
}

\author{
By Bridget Heal
}

Protestantism was, without doubt, a religion of the Word. During the early modern period, Lutheran religious life was built around the spoken and printed word: around the sermon; around the use of catechisms, prayer books and hymnals; and around Luther's own translation of the Bible. The Wittenberg Reformation matured alongside the printing press, and vernacular print production - from polemical pamphlets to Bibles, catechisms and spiritual literature - was crucial to its history. The word had, as Thomas Kaufmann has recently argued, a "culture-shaping significance" for Lutheranism everywhere. Books not only disseminated Luther's message but also became the most "profound symbol of Lutheran confessionalism." This powerful paradigm of a word- and book-oriented Protestant piety and identity has, for too long, co-existed with a narrative that recounts the rejection of visual piety and marginalization of religious art. Reformation historians have recognized that Lutherans made extensive use of visual propaganda, and that the Wittenberg workshop of Lucas Cranach and his son produced numerous images in the service of Luther and his supporters. But Lutheran art is still characterised as primarily polemical and pedagogical, as unnecessary and incidental to true, word-based Protestant piety and to Lutheran confessional identity.

In this brief essay I shall focus on one particular genre of Lutheran religious image: Bible illustration. The Bible - in particular in the reformer's own 1545 translation - lay at the very heart of Lutheran culture. In Jonathan Sheehan's words, "the Reformation made the Protestant Bible the engine of political, religious, and imaginative life, an engine defended and

1. Thomas Kaufmann, "What is Lutheran Confessional Culture?," in Per Ingesman, ed., Religion as an Agent of Change: Crusades - Reformation - Pietism (Leiden: Brill, 2016), 127-148, here 132, 134. See also Etienne François, "Das religiöse Buch als Nothelfer, Familienreliquie und Identitätssymbol im protestantischen Deutschland der Frühneuzeit (17.-19. Jahrhundert)," in Ursula Brunold-Bigler, Hermann Bausinger, ed., Hören Sagen Lesen Lernen: Bausteine zu einer Geschichte der kommunikativen Kultur. Festschrift für RudolfSchenda zum 65. Geburtstag (Bern u.a.: Lang, 1995), 219-230. 
treasured well into the nineteenth century."2 In encomia to the vernacular Bible, whether written by early modern theologians or modern scholars, it is always its text that is praised. Yet from the very beginning many Lutheran Bibles, as well as many Lutheran catechisms and devotional texts, were illustrated. Let us begin, therefore, in the context of this discussion of the Reformation's long-term impact, with a story from the age of the Enlightenment and Romanticism, a story that testifies to the ongoing power of the Lutheran Bible's images rather than its words.

From March to May 1787 Johann Wolfgang von Goethe was travelling in Sicily. His return journey from Messina to Calabria was not a happy one he was suffering from seasickness, aboard an uncomfortable French ship crewed, he believed, by incompetents. The ship was blown off course and was eventually caught in the current surrounding Capri, drawn towards a sheer rock face. Goethe, in heroic and ironic fashion, addressed his panicked fellow passengers, telling them as Catholics to pray to the Virgin Mary. Of course nothing happened, and the ship came so close to the rocks that the crew took up poles ready to push it away if necessary. "The violence of the surf seemed to be increasing, the ship tossed and rolled more than ever; as a result, my seasickness returned and I had to retire to the cabin below. I lay down half dazed but with a certain feeling of contentment, due, perhaps, to the sea of Tiberias; for, in my mind's eye, I saw clearly before me the etching from the Merian Bible. It gave me proof that all impressions of a sensory-moral nature are strongest when a man is thrown completely on his own resources."

Goethe was by this time turning into a worshiper of art and nature alone, with a strong preference for Greek gods over the one Christian God. He was also no great devotee of "Gothic" art. In the sixteenth century religious images had fallen victim to iconoclasts' axes; in the eighteenth they fell victim to the artistic taste of the time, which was directed above all towards classical antiquity. Late medieval and Reformation images were removed from churches, and the art of the Reformation languished in relative obscurity until its rediscovery and installation in museums during the nineteenth century. Yet

2. Jonathan Sheehan, The Enlightenment Bible: Translation, Scholarship, Culture (Princeton: Princeton University Press, 2005), 1.

3. Johann Wolfgang von Goethe, Italian Journey, trans. by W. H. Auden (London: Pantheon Books, 1970), 307. 
Goethe was comforted in a moment of crisis by an image from the illustrated Bible that he knew from his Lutheran childhood in Frankfurt am Main (figure 1).

The Merian Bible to which Goethe referred was produced, in its first edition, in Straßburg in 1630. It is a magnificent work: folio format, with numerous high-quality engravings that had appeared first of all in Matthaeus Merian's Icones Biblicae (1625-27). ${ }^{4}$ The text of the Merian Bible is Luther's canonical 1545 version, the last to which the reformer himself made corrections during his lifetime. The Bible's preface notes that it was printed on the 100th anniversary of the Augsburg Confession, a very clear statement of Lutheran confessional identity in the midst of the traumas of the Thirty Years' War. For the next hundred years, the workshop run by Merian's heirs continued to produce new editions. In southern Germany, Basel and Alsace in particular, Merian's became the most popular German Bible, at least among the wealthy. Moreover, the engravings, whether taken from the Icones Biblicae or from the Merian Bible itself, were copied numerous times in various media: not only in later illustrated Bibles (both Protestant and Catholic), but also in paintings on the galleries of churches. Indeed, the Katharinenkirche in Frankfurt, where Goethe attended services as a child, contained a series of gallery paintings based in part on Merian's engravings that had been installed in the 1680s at the behest of Philipp Jakob Spener, the founding father of Pietism. $^{5}$

The Merian Bible represents a high point in the history of illustrated Lutheran Bibles, a history that began in Wittenberg with Luther himself. In the New Testament that Luther hurried to produce in September 1522, only the book of Revelation was illustrated - with Lucas Cranach the Elder's sharply anti-papal woodcuts. Luther's Old Testament translations, as they appeared gradually between 1523 and 1534, did contain images, and his first complete Bible, printed in Hans Lufft's workshop in 1534, was also carefully illustrated with a cycle of 117 new woodcuts produced in the Cranach workshop by an artist who signed himself as "Master MS." But even in 1534 the Gospels and Acts of the Apostles - the central records of Jesus' ministry on earth -

4. Lucas Heinrich Wüthrich, Matthaeus Merian d.Ä.: Eine Biographie (Hamburg: Hoffmann und Campe, 2007), $132 \mathrm{ff}$.

5. Joachim Proescholdt, ed., St. Katharinen zu Frankfurt am Main (Frankfurt am Main: Kramer, 1981), esp. Maria Lilek-Schirmer, “Die Emporengemälde: Eine Bilderpredigt," 164-188. 
remained entirely image-less. ${ }^{6}$ Gradually, however, during the later sixteenth and seventeenth centuries, images crept into these key texts. Images became an important element of Lutherans' experience of all parts of Scripture, as Goethe's vision suggests.

Why were there images in these Bibles? Why was the pure Word of God accompanied, in many cases, by visual distractions? Luther's own justifications for religious images are well known: images were matters of Christian freedom, they could be used for commemoration and as witnesses to God's merciful works. In the preface to his illustrated 1529 prayer book Luther wrote that this "lay Bible" was necessary because "one cannot present the Word and work of God too much or too often to the common man, if one sings and speaks of it, makes sounds [klinget $]$ and preaches, writes and reads, paints and draws." ' Images - above all spiritual or internal - were also for Luther inevitable parts of religious experience: "whether I want to or not, when I hear the word of Christ, there delineates itself in my heart a picture of a man who hangs on the cross," he commented in Against the Heavenly Prophets. ${ }^{8}$ Under pressure from Calvinist iconoclasm, Lutheran theologians defended images in more detail and at greater length during the late sixteenth and early seventeenth centuries. ${ }^{9}$ At the same time the Frömmigkeitsbewegung, the movement for the renewal of spiritual life that had Johann Arndt as its greatest exponent, assigned religious images a new value, arguing that they, like music, could play a part in Einbildung, the process by which God's word was impressed upon the human heart.

Matthaeus Merian's own writings provide a good entry point for considering the role that images had come to play in Lutheran piety and confessional identity by the early seventeenth century. Merian is famous today above all for his series of topographical engravings, which looked back to the glory of the Holy Roman Empire before the destruction of the Thirty Years' War. He was born in Basel, studied in Paris and elsewhere, and spent most of his career in Frankfurt, where

6. For an overview see Phillip Schmidt, Die Illustration der Lutherbibel, 1522-1700: Ein Stück abendländische Kultur- und Kirchengeschichte (Basel: Reinhardt, 1962).

7. Martin Luther, "Betbüchlein," D. Martin Luthers Werke: Kritische Gesamtausgabe, 73 vols. (Weimar: Böhlau, 1883-2009), vol. 10.2 (1907), 331-495, here 458-459.

8. Translation and full discussion in Joseph Koerner, The Reformation of the Image (London: Reaktion Books, 2004), 160.

9. Thomas Kaufmann, Konfession und Kultur: Lutherischer Protestantismus in der zweiten Hälfte des Reformationsjabrhunderts (Tübingen: Mohr Siebeck, 2006), ch. 5. 
in 1623 he took over the de Bry publishing house. ${ }^{10}$ In $1625-27$ he published the Icones Biblicae, an album of Scriptural images, each of which was accompanied by short verses in Latin, German, and French. No Protestant author ever produced a defence of sacred images that was as detailed or as sophisticated as those written by the great Catholic apologists of the time, men such as Johannes Molanus and Gabriele Paleotti. But the prefaces to "image Bibles" such as Merian's did reflect on the role of the visual in religious devotion, and helped to construct and to disseminate a specifically Lutheran theology of images.

Not surprisingly perhaps, given that it is written by an artist, Merian's commentary opens with a lengthy discussion of the arts, in particular the "free art of painting," which he describes as waxing and waning like the moon, from the glory of ancient Rome, through the barbarous times of the Goths, Lombards and Huns, to a revival under Emperors Frederick III and Maximilian I. The culmination of this revival was the work of the great German artists of the Renaissance: Albrecht Dürer, Lucas Cranach, and Hans Holbein, who could "rightly be described as the German Apelles, Zeuxis, and Parrhasius." 11 Such appreciation of images' cultural and aesthetic value had not been a standard part of early evangelical discourse: Luther, for example, never invoked images' beauty as a reason for their retention. Rather, aestheticism emerged as a theme during the second half of the sixteenth century, above all in the prefaces to cycles of biblical images - precursors of Merian's Icones Biblicae that were intended to educate the laity but also to tempt wealthy purchasers and to serve as pattern books for artists.

In the age of princely and patrician collecting, the authors and publishers of such texts recognized the importance of aesthetic appreciation as a means of reinforcing social distinction. Tobias Stimmer's Neue Künstliche Figuren, printed in 1576 in Basel, was intended, for example, for people who were "learned in art," while Merian addressed himself to "people who fear God and understand art." Artistic skill also, however, reinforced the perceived spiritual effectiveness of the image. Merian wrote that those to whom God had given

10. On the Topographia Germaniae see Ulrike Valerie Fuss, Matthaeus Merian der Ältere: Von der lieblichen Landschaft zum Kriegsschauplatz - Landsschaft als Kulisse des 30jährigen Krieges (Frankfurt am Main et al.: Lang, 2000), here 133. On Merian see Wüthrich, Matthaeus Merian (see note 4).

11. Icones Biblice Pracipuas Sacre Scripture Historias eleganter \& graphice representantes. Biblische Figuren / darinnen die Fürnembsten Historien / in Heiliger vnnd Göttlicher Schrifft begriffen / Gründtlich und Geschichtsmessig entworfen [...] (Frankfurt: De Bry, 1625), fol. A iii r. 
artistic ability should make proper use of their talents, with the help of discerning patrons. He, Merian, had therefore undertaken to illustrate Scripture "not only for entertainment and pleasure, but also, and most importantly, to excite the soul to pious thought and contemplation of the stories depicted."12 Merian's engravings are exquisite. They are set apart from what had gone before above all by their detailed representation of nature; in this regard they constitute a visual precursor to the physico-theology of the Enlightenment era. Here in 1625-27, however, Merian's images reflected a general contemporary interest in the spiritual contemplation of nature. ${ }^{13}$

After his discussion of the arts, Merian addressed images' pedagogical and devotional functions: their ability to lead their viewers to contemplate and understand Scripture. The recognition that images move - movere or bewegen - their beholders is there already in Luther's writings, but for him images should move not to an openly affective response - to tears, for example, as late medieval Passion iconography had done - but to memory or recollection. Merian's understanding was rather different. He wrote in the preface to his Icones Biblicae: "There is no doubt, since objects move the senses, that through straightforward [vnpassionirter] contemplation of these figures the soul [Gemüthe] will find itself very differently engaged than in consideration of frivolous paintings of Venus, the shameful obscenities of Pietro Aretino and similar scandalous inventions." ${ }^{14}$

Here Merian, who was himself eventually accused by Frankfurt's city council of associating with Spiritualist followers of Valentin Weigel, echoed the ideas of the Frömmigkeitsbewegung in his characterization of the power of visual contemplation. Arndt, for example, in his 1596 Ikonographia, had stated that no Christian heart could object to images of Christ's Passion, for "the Holy Spirit forms in your heart that which you see externally." ${ }^{5}$ Simon Gedicke, writing from Saxony in 1615 in response to Brandenburg's Calvinist iconoclasm, argued that "what a man sees before his eyes goes to his heart and

12. Ibid.

13. See, for example, Johann Arndt, Ikonographia (1597), ed. by Johann Anselm Steiger (Hildesheim et al.: Olms, 2014), 81ff.

14. On the origin and use of the phrase "obiecta mouent sensus" see Gabriele Wimböck, "Durch die Augen in das Gemüt kommen': Sehen und Glauben - Grenzen und Reservate," in Gabriele Wimbock, Karin Leonhard, Markus Friedrich, ed., Evidentia: Reichweiten visueller Wahrnehmung in der Frühen Neuzeit (Berlin: Lit-Verlag, 2007), 427-452, here 440.

15. Arndt, Ikonographia (see note 13), 60. 
moves him." ${ }^{16}$ Johann Valentin Andreae in his 1619 Christianopolis, a Utopian description of an ideal Christian community, described a statue of "the crucified Christ, so skilfully made as to move even the hardest of hearts." ${ }^{17}$ From the later sixteenth century onwards, images were, these authors demonstrate, accorded an important role in Verinnerlichung, in the process by which intellectual knowledge of God was transformed into his affective presence in the soul.

During the seventeenth century, the Lutheran conviction that images provided a powerful didactic and devotional tool led to the development of ingenious image-based works of biblical instruction, which responded to the pedagogical innovations of the time. Sigismund Evenius' Christliche Gottselige Bilder Schule was one of the earliest, printed in Jena in 1636 and intended, according to its preface, for teaching at school and in the home children as young as three, four, and five. ${ }^{18}$ In his preface Evenius wrote of the use of physical images from the time of the Apostles via Tertullian, Gregory of Nyssa, Eusebius, and Gregory the Great, to Luther and beyond. Biblical images were, he wrote, published during Luther's lifetime, and had thereafter "from year to year multiplied and improved," until the final emergence of emblematic images with their explanatory texts. Although Evenius clearly did not believe that images alone could teach - each of his has an over-abundance of interpretative text - his work pushed visual pedagogy in new directions, making physical images the centrepieces of understanding and remembering. Other seventeenth-century experiments included Johannes Buno's Bilderbibel, published in Hamburg in 1680, which took the Lutheran art of visual mnemonics to an entirely new level. Buno's work comprised over 1,000 pages of octavo text, with a separate volume of 70 images, and sought to put before its readers' eyes things that were "difficult to grasp [...] and escape the memory again quickly, such as numbers, strange and unknown names and words, and the like." 19 There were also

16. Simon Gedicke, Calviniana oder Calvinisterey / So fälschlich die Reformierte Religion genennet wird [...] (Leipzig: Abraham Lamberg, 1615), 500.

17. Johannes Valentinus Andreae, Christianopolis, ed. by Edward H. Thompson (Dordrecht: Kluwer, 1999), 257-258.

18. For a general discussion of the text see Ingrid Hruby, "1636. Sigismund Evenius: Christliche / Gottselige Bilder Schule" in Theodor Brüggemann, ed., Handbuch zur Kinder- und Jugendliteratur: Von 1570 bis 1750 (Stuttgart: J. B. Metzler, 1991), 145-156.

19. Johannes Buno, Bilder-Bibel (Hamburg: Lichtenstein, 1680), Vorrede. See Gerhard F. Strasser, Emblematik und Mnemonik der Frühen Neuzeit im Zusammenspiel: Johannes Buno und 
Bibles that adopted a hieroglyphic principle, replacing individual words with images. Melchior Mattsperger's Geistliche Herzens-Einbildungen was published in Augsburg in 1685. It was intended, according to its preface, for young and simple folk, and worked on the principle that "when this or that word is expressed through an image, it will both lie in the heart and shape it more." 20

By the end of the seventeenth century, images' roles in Lutheran education and devotion were well established, though still not entirely uncontested. What happened as Protestantism started to become a global religion? Images were certainly exported with Protestantism to the New World. Mattsperger's 1685 hieroglyphic Bible was, for example, the precursor to a whole genre of such books that remained popular in both Europe and North America for more than two hundred years. And although New England meeting houses were functionalist and sparsely ornamented, emblems, such as those favoured by Mattsberger, were frequently used on tombstone carving. ${ }^{21}$ We know that images constituted an important part of Catholic - especially Jesuit - mission strategy. We tend to assume, however, that Protestantism's earliest active missionaries, the Halle Pietists, did not make use of images. The traditional view of Halle Pietism as hostile to the visual arts has been revised in recent years, but August Hermann Francke certainly rejected Buno's Bilderbibel and warned that the engravings in image bibles were "seldom made with understanding, and often brought children more damage than profit." 22 A letter preserved in the Franckesche Stiftungen suggests, however, that some of his followers were alert to images' potential. In 1737 Johann Ernst Geister, who had travelled from Halle to Madras and then established a mission in Cuddalore, wrote to a pastor in Halle expressing his pleasure at the receipt of an image Bible. ${ }^{23}$ As the efforts of the Halle missionaries were reinforced by those of the Moravian Brethren in particular, it seems likely that Protestant willingness to use

\footnotetext{
Johann Justus Winckelmann (Wiesbaden: Harrassowitz, 2000), esp. 86-87.

20. See Ulrich Kreidt, "1684/92. Melchior Mattsperger: Geistliche Herzens = Einbildungen," in Brüggemann, ed., Handbuch (see note 18), 171-190.

21. William A. Dyrness, Reformed Theology and Visual Culture: The Protestant Imagination from Calvin to Edwards (Cambridge: Cambridge University Press, 2004), $252 \mathrm{ff}$.

22. Christine Reents, Christoph Melchior, Die Geschichte der Kinder- und Schulbibel: Evangelisch - katholisch - jüdisch (Göttingen: Vandenhoeck \& Ruprecht, 2011), 202.

23. Franckesche Stiftung zu Halle, Das Missionsarchiv mit der Indien- und Amerikaabteilung (AFSt/M), 2 G 11: 64.
} 
images in missionary activity increased. Nikolaus Ludwig von Zinzendorf was himself well aware of images' affective power, and developed a "religion of the heart" that was expressed both verbally and visually, for example in depictions of Christ's blood and wounds. ${ }^{24}$

Given the importance accorded to images in Lutheran Bibles and in other works of religious instruction we should perhaps not be surprised to find that Goethe, confronted by the power of nature and the incompetence of French sailors, derived comfort from an image from the Merian Bible that he knew from his Lutheran youth. Goethe was, of course, writing at a moment that we associate with a transition in aesthetic sentimentality, at a moment in which ego-documents started to dwell in new and explicit ways on the emotional character of individual experience. We will never be able to trace, for an earlier period, the psychological impact of religious images that Goethe's shipwreck story reveals so nicely. But it is clear from their "image theology," if we can call it that, that Matthaeus Merian and his contemporaries hoped and expected to create precisely such an impact. To be sure, aestheticism always sat somewhat uncomfortably side-by-side with commitment to the pure Word of God, as Pietist criticisms of baroque art and music demonstrate. And to be sure, didacticism was always the primary Lutheran justification for images. But to characterize Lutheran art as an emotional blank and to conceive of it as dry and intended only to teach the basic precepts of the faith, is wrong. The religious function of Lutheran images quite clearly extended beyond the "didactic and commemorative" to encompass the "sensual and aesthetic." 25 With the renewal of a culture of affective piety in the late sixteenth century, and with the flourishing of Lutheran pedagogy in the seventeenth, evangelicals showed a great willingness to harness the beauty and emotive force of images, to employ them in their campaigns for spiritual and moral renewal. They developed a theologically grounded aesthetic, in which images' beauty was understood to reinforce their spiritual significance. And as Goethe's story suggests, even once eigh-

24. See Margit Kern, “'Zinzendorf als Lehrer der Völker' - Visualisierungsformen von Glaubensbekenntnis, Kirche und Mission in der Frühen Neuzeit," in Christian Soboth, Thomas Müller-Bahlke, ed., Reformation und Generalreformation - Luther und der Pietismus (Halle: Verlag der Franckeschen Stiftungen, 2012), 97-124.

25. Thomas Kaufmann "Die Sinn- und Leiblichkeit der Heilsaneignung im späten Mittelalter und in der Reformation," in Johanna Haberer, Berndt Hamm, ed., Medialität, Unmittelbarkeit, Präsenz: Die Nähe des Heils im Verständnis der Reformation (Tübingen: Mohr Siebeck, 2012), 11 44 , here 25 . 
teenth-century arbiters of taste excluded Cranach and his followers from their critical canon, Reformation art continued, via the medium of illustrated Bibles, to shape Protestant sensibilities.

\section{Dr Bridget Heal \\ School of History \\ University of St Andrews \\ St Katharine's Lodge \\ The Scores \\ St Andrews, Fife KY16 9BA \\ United Kingdom \\ bmb6@st-andrews.ac.uk}

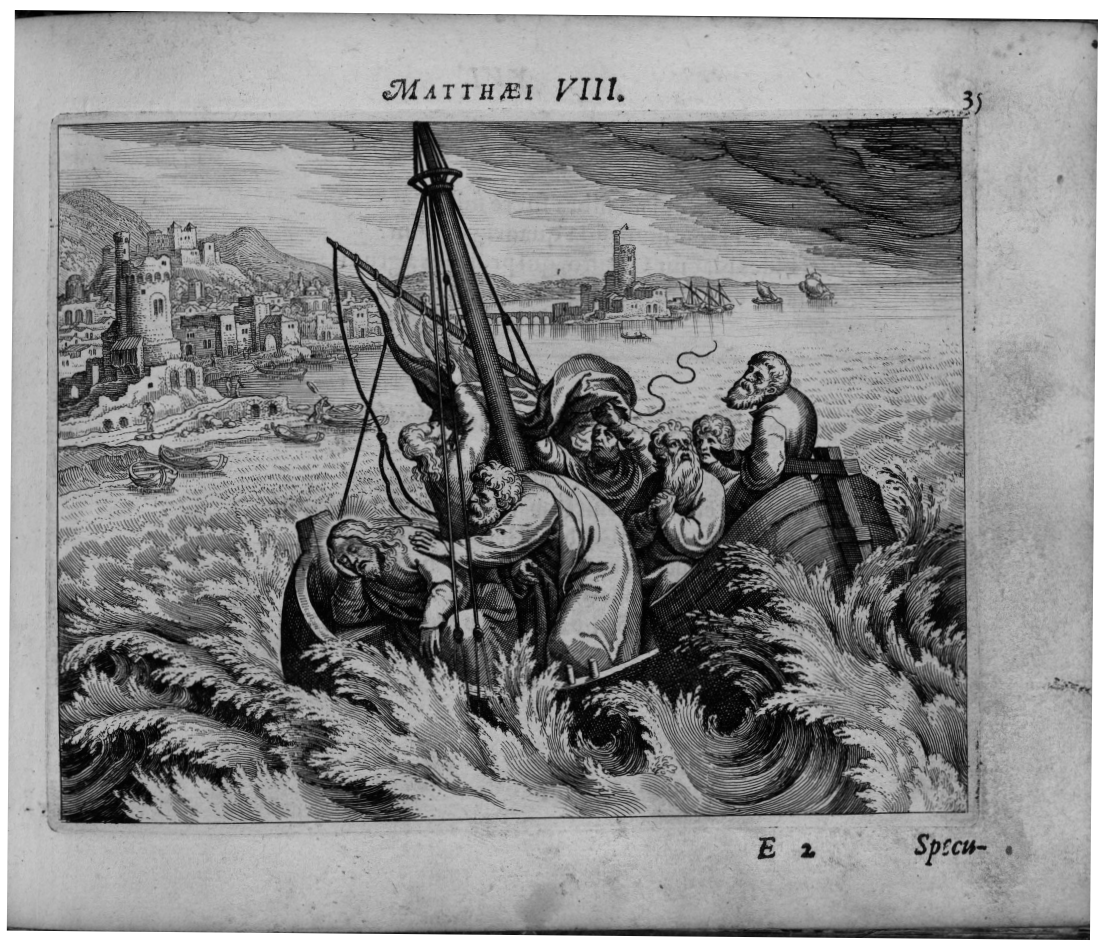

Figure 1: Matthaeus Merian the Elder, Icones Biblicae [4] Novi Testamenti D. N. Jesu Christi (Straßburg: Zetzner, 1627). Staatsbibliothek Bamberg, class mark A. symb. q.23\#4 (VD 17 $14: 641632 \mathrm{E})$. 